\title{
KRYTERIUM POWSTAWANIA STRUGI SYNTETYCZNEJ
}

\begin{abstract}
W pracy przedstawiono kryterium powstawania strugi syntetycznej. Zaprezentowano wyniki pomiaru prędkości powietrza w osi dyszy generatora strugi syntetycznej dla zmiennej częstotliwości $f=5-400 \mathrm{~Hz}$ generatora, zmiennej średnicy dyszy $d=15,24,40 \mathrm{~mm}$ oraz zmiennej głębokości komory rezonansowej generatora $H=20,40,60 \mathrm{~mm}$. Dokonano pomiaru mocy elektrycznej przetwornika elektroakustycznego. Porównano uzyskane wartości liczb Reynoldsa oraz Stokesa z danymi literaturowymi oraz warunkiem powstawania strugi syntetycznej, uzyskując zbieżność otrzymanych wyników.
\end{abstract}

Słowa kluczowe: struga syntetyczna, liczba Reynoldsa, kryterium powstawania strugi, częstotliwość rezonansowa

\section{Wprowadzenie}

Struga syntetyczna jest rodzajem przepływu wytwarzanym przez ścieżkę wirów pierścieniowych. Strugi syntetyczne mogą mieć zastosowanie w chłodzeniu elektroniki, sterowaniu przepływem lub w wytwarzaniu turbulentnej warstwy przyściennej. Pierwsze prace na temat strugi syntetycznej pojawiły się w latach 50. XX w. [1]. Wówczas tematyka ta nie wywołała większego zainteresowania. Dopiero w 1997 r. w pracy [2] przypomniano znów to zagadnienie i od tamtej pory liczba publikacji na ten temat wciąż rośnie. Struga syntetyczna, określana również ZNMF, jest wytwarzana za pomoca generatora o pracy periodycznej. Cechą charakterystyczną urządzeń wytwarzających strugę syntetyczną jest brak zewnętrznego doprowadzenia płynu. Do działania niepotrzebne są zatem kanały doprowadzające czynnik roboczy, a uśredniony w czasie wydatek masowy przepływający przez dyszę jest równy zeru. W odróżnieniu od typowych maszyn przepływowych generatory strugi syntetycznej mają zdolność do generowania transportu pędu i energii przy braku przepływu masy przez to urządzenie [3]. Chaudhari i in. [4] zbadali prędkość wypływu powietrza z generatora

\footnotetext{
${ }^{1}$ Autor do korespondencji/corresponding author: Paweł Gil, Politechnika Rzeszowska, al. Powstańców Warszawy 8, 35-959 Rzeszów, tel.: (17) 8651326, e-mail: gilpawel@ prz.edu.pl

${ }^{2}$ Piotr Strzelczyk, Politechnika Rzeszowska, e-mail: piotstrz@prz.edu.pl
} 
strugi syntetycznej przy różnych średnicach dysz $d$ i głębokości komory $H$ w funkcji częstotliwości. Wykazali, że najwyższe wartości prędkości średniej (i liczby Reynoldsa) generator osiagga dla częstotliwości rezonansowej przetwornika. Wówczas moc elektryczna jest mniejsza niż w innym zakresie częstotliwości o około 30\%. Smith i Glezer [3] porównywali strugę syntetyczną ze struga swobodną dla tych samych liczb Reynoldsa. Z uzyskanych danych wynika, że struga syntetyczna w bliskiej odległości jest zdominowana przez wiry pierścieniowe, które zasysają dodatkowy płyn do środka wiru, w dalekiej zaś odległości od dyszy generatora struga syntetyczna wykazuje duże podobieństwo do strugi ciagłej. Oznaczenie stosowanych do opisu analizowanych zagadnień zestawiono w tabeli 1. Oznaczenia wielkości stosowanych do opisu analizowanych zagadnień zestawiono w tab. 1 .

Tabela 1. Oznaczenia

Table 1. Nomenclature

\begin{tabular}{|c|c|c|c|}
\hline Symbol & Objaśnienie, jednostka & Symbol & Objaśnienie, jednostka \\
\hline $\begin{array}{c}d \\
d_{m} \\
f \\
f_{H} \\
f_{s} \\
\\
H \\
I \\
m \\
n \\
P \\
R \\
r \\
\text { Re } \\
\text { Stk }\end{array}$ & $\begin{array}{c}\text { średnica dyszy }[\mathrm{mm}] \\
\text { średnica membrany }[\mathrm{mm}] \\
\text { częstotliwość pracy } \\
\text { częstotliwość Helmholtza }[\mathrm{Hz}] \\
\text { częstotliwość rezonansowa }[\mathrm{Hz}] \\
\text { głośnika }[\mathrm{Hz}] \\
\text { głębokość komory [mm] } \\
\text { natężenie prądu głośnika }[\mathrm{A}] \\
\text { masa membrany }[\mathrm{g}] \\
\text { liczba pomiarów } \\
\text { moc głośnika }[\mathrm{W}] \\
\text { rezystancja opornika }[\Omega] \\
\text { współrzędna promieniowa }[\mathrm{mm}] \\
\text { liczba Reynoldsa } \\
\text { liczba Stokesa }\end{array}$ & $\begin{array}{c}t \\
T \\
U \\
U_{c h} \\
U_{\text {avg }} \\
U_{I} \\
U_{\mathrm{RMS}} \\
V \\
x \\
v \\
\varphi\end{array}$ & $\begin{array}{c}\text { długość dyszy }[\mathrm{mm}] \\
\text { temperatura otoczenia }\left[{ }^{\circ} \mathrm{C}\right] \\
\text { napięcie zasilania głośnika }[\mathrm{V}] \\
\text { prędkość chwilowa }[\mathrm{m} / \mathrm{s}] \\
\text { wartość średnia prędkości }[\mathrm{m} / \mathrm{s}] \\
\text { spadek napięcia na rezystorze } \\
\text { wzorcowym [V] } \\
\text { wartość skuteczna } \\
\text { prędkości }[\mathrm{m} / \mathrm{s}] \\
\text { objętość komory }\left[\mathrm{mm}^{3}\right] \\
\text { współrzędna osiowa }\left[\mathrm{mm}^{2}\right] \\
\text { lepkość kinematyczna }\left[\mathrm{m}^{2} / \mathrm{s}\right] \\
\text { wilgotność względna } \\
\text { powietrza [\%] }\end{array}$ \\
\hline
\end{tabular}

\section{Stanowisko pomiarowe}

Komora generatora strugi syntetycznej zbudowana do celów badawczych została przedstawiona na rys. 1. Składa się z przetwornika elektroakustycznego (głośnika) o średnicy $160 \mathrm{~mm}$ jako elementu wykonawczego, zamontowanego w wyfrezowanej płycie ze szkła organicznego mającego otwór o średnicy $150 \mathrm{~mm}$. Płyta zamykająca komorę posiada cylindryczną dyszę o średnicy $d$ oraz długości $t$. W prezentowanych wynikach wykorzystywano średnicę dyszy $d=15,24,40 \mathrm{~mm}$ oraz stałą długość dyszy $t=5 \mathrm{~mm}$. Płyty zamykające są wymienne, tak aby można było zastosować dyszę o różnych średnicach i długościach. Objętość komory $V$ jest regulowana. Polega to na dodaniu lub odjęciu płyt pośrednich pomiędzy przetwornikiem elektroakustycznym a płytą zamykająca. Głębokość komory $H$ zmienia się w zakresie 20-60 mm. 
Generator strugi syntetycznej jest zasilany wzmacniaczem mocy zbudowanym na podstawie układu scalonego LM3886 zasilanego symetrycznie, z kondensatorami separującymi. Wzmacniacz jest podłączony do wyjścia analogowego karty dźwiękowej posiadającej przetwornik cyfrowo-analogowy (DAC) 16-bitowy. Częstotliwość próbkowania wynosi $48 \mathrm{kHz}$. Podczas wykonywania badań częstotliwość wzbudzenia membrany przetwornika elektroakustycznego $f$ zmieniała się w zakresie $5-400 \mathrm{~Hz}$.

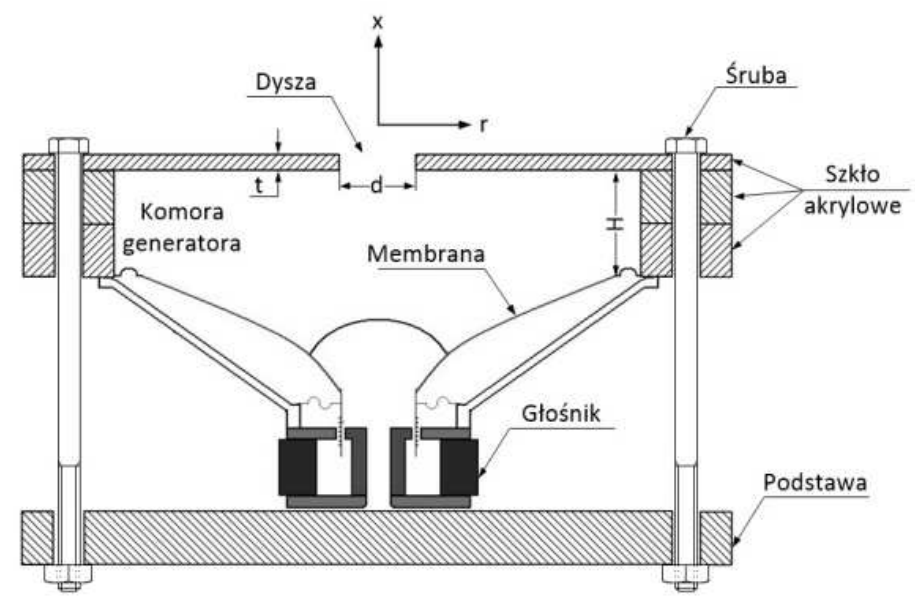

Rys. 1. Generator strugi syntetycznej

Fig. 1. Synthetic jet generator

Zastosowano 8-omowy głośnik STX 6,5 200. Przetwornik elektroakustyczny był zasilany napięciem przemiennym o przebiegu sinusoidalnym, ze wzmacniacza mocy o wartości skutecznej napięcia stałej dla wszystkich pomiarów $U=4 \mathrm{~V}$. Moc pobieraną przez generator określono jako iloczyn napięcia skutecznego zmierzonego na głośniku $U$ oraz natężenia skutecznego prądu pobranego $I$. Natężenie prądu płynącego przez przetwornik było obliczone jako spadek napięcia $U_{I}$ na rezystorze wzorcowym $R=0,1 \Omega$. Pomiaru napięcia i spadku napięcia na rezystorze wzorcowym dokonano za pomocą multimetru Keithley 2700. Moc głośnika została obliczona z zależności:

$$
P_{g}=U \frac{U_{I}}{R}
$$

Do pomiaru prędkości powietrza w osi membrany zastosowano termoanemometr stałotemperaturowy jednowłóknowy HPA 98 o średnicy włókna $5 \mu \mathrm{m}$ oraz długości włókna $1 \mathrm{~mm}$. Włókno zostało wykonane z wolframu. Sygnał napięciowy był rejestrowany za pomocą karty pomiarowej KPCI-3116A firmy 
Keithley. Częstotliwość próbkowania dobierano automatycznie jako szesnastokrotność częstotliwości pracy generatora strugi syntetycznej.

Termoanemometr został przewzorcowany w tunelu aerodynamicznym w zakresie 0,7-20,0 m/s. Punkty wzorcowe aproksymowano wielomianem 6 . stopnia w zakresie $0,7-20,0 \mathrm{~m} / \mathrm{s}$, z maksymalnym błędem $2,7 \%$. Pomiary wykonywano $\mathrm{w}$ klimatyzowanym laboratorium o temperaturze $T=21 \pm 1{ }^{\circ} \mathrm{C}$. Wilgotność względną oraz temperaturę powietrza mierzono higrometrem Testo 6681. Wilgotność względna $\mathrm{w}$ pomieszczeniu podczas pomiarów wynosiła $\varphi=$ $(50 \pm 8) \%$. Płynem generatora strugi syntetycznej było powietrze atmosferyczne.

Sondę termoanemometru ustawiono w osi dyszy, równo z powierzchnią wylotu dyszy $x=0 \mathrm{~mm}$ (rys. 1.). Generator strugi syntetycznej był ustawiony poziomo. Dla każdego punktu pomiarowego dokonywano pomiaru 50 cykli, każdy po 16 próbek. Kierunek prędkości nie może być określony z pomiarów termoanemometru. Na podstawie zarejestrowanego modułu prędkości dokonano inwersji połówki sinusoidy odpowiadającej za cykl zasysania powietrza do komory. Wykorzystano w tym celu procedurę opisaną w pracy [5].

Rysunek 2. przedstawia przykładowy przebieg prędkości powietrza w osi dyszy. Większy pik na rys. 2. odpowiada za cykl wytłaczania, natomiast mniejszy - zasysania. W celu określenia kierunku prędkości został napisany program w środowisku LabVIEW, który przeprowadza obliczenia dla każdego punktu pomiarowego z 800 pomiarów prędkości. Zarejestrowany przebieg prędkości z kierunkiem posłużył do obliczenia następujących wielkości jako średniej z 50 cykli [1]:

- prędkości średniej

$$
U_{a v g}=\frac{\sum U_{C h}}{n}
$$

- wartości skutecznej prędkości

$$
U_{\mathrm{RMS}}=\sqrt{\frac{\sum\left(U_{C h}-U_{\text {avg }}\right)^{2}}{n}}
$$

- liczby Reynoldsa

$$
\operatorname{Re}=\frac{U_{a v g} \cdot d}{v}
$$

- liczby Stokesa

$$
\mathrm{Stk}=\sqrt{\frac{2 \pi f d^{2}}{v}}
$$




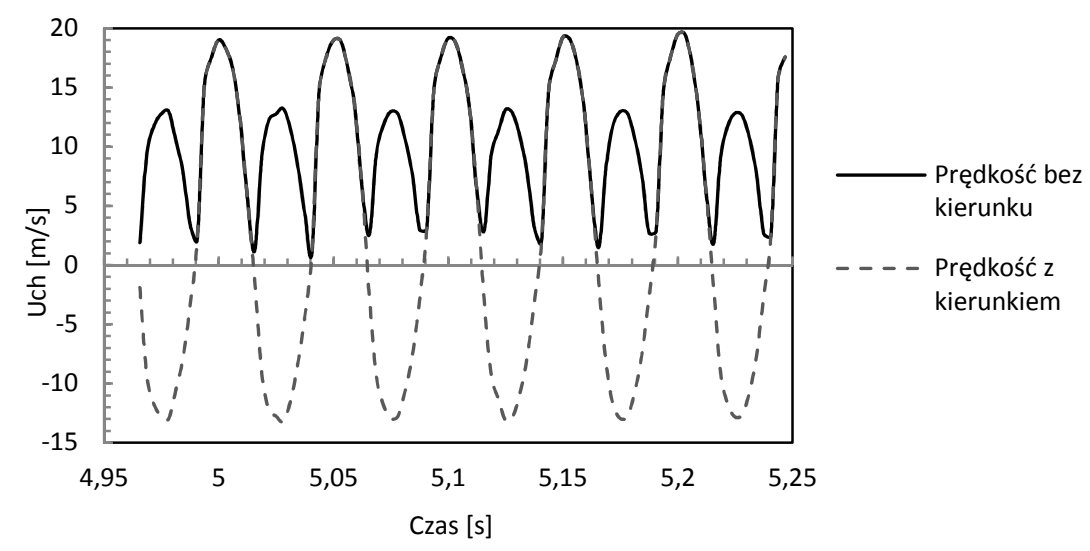

Rys. 2. Przykładowy wykres zmienności prędkości powietrza w osi dyszy generatora strugi syntetycznej

Fig. 2. Example plot of air velocity fluctuation in the nozzle axis of synthetic jet generator

\section{Wyniki}

Na podstawie zestawu pomiarowego uzyskano wyniki zobrazowane na rys. 3-8. Na rysunkach 3. oraz 4. przedstawiono moc elektryczną głośnika. Głośnik zabudowany w komorze posiada częstotliwość, przy której moc pobrana osiaga lokalne minimum. Jest to częstotliwość rezonansowa membrany. Lokalne minimum mocy elektrycznej zostało osiagnnięte dla częstotliwości $f=35 \mathrm{~Hz}$. Przy zwiększającej się średnicy dyszy pobrana moc elektryczna głośnika maleje (rys. 4.). Rysunki 5. oraz 6. pokazują średnią prędkość w osi dyszy w odniesieniu do różnych średnic dyszy (rys. 5.) oraz różnych głębokości komory (rys. 6.). Średnia prędkość $U_{\text {avg }}$ szybko rośnie do wartości szczytowej, która występuje dla częstotliwości $f=35 \mathrm{~Hz}$, a następnie powoli się zmniejsza wraz ze zwiększaniem częstotliwości generatora strugi syntetycznej. Na rysunku 7. przedstawiono wartość skuteczną prędkości powietrza w osi dyszy $U_{\text {RMS }}$, przy czym wartości szczytowe osiagnięto dla $35 \mathrm{~Hz}$. Przy różnych średnicach dysz osiagano różne wartości prędkości skutecznej. Dla $d=15 \mathrm{~mm}$ wartości maksymalne sięgaja $12,5 \mathrm{~m} / \mathrm{s}$, dla $d=24 \mathrm{~mm}$ już tylko $8 \mathrm{~m} / \mathrm{s}$, a dla $d=40 \mathrm{~mm}$ wartości prędkości skutecznej nie przekraczają $4 \mathrm{~m} / \mathrm{s}$. Rysunek 8 . przedstawia wartość prędkości skutecznej dla tej samej średnicy dyszy $d=15 \mathrm{~mm}$, lecz zmiennej objętości komory $V$. W zakresie częstotliwości rezonansowej wpływ głębokości komory na $U_{\mathrm{RMS}}$ oraz moc głośnika $P_{g}$ jest niewielki (rys. 4. i 8.). 


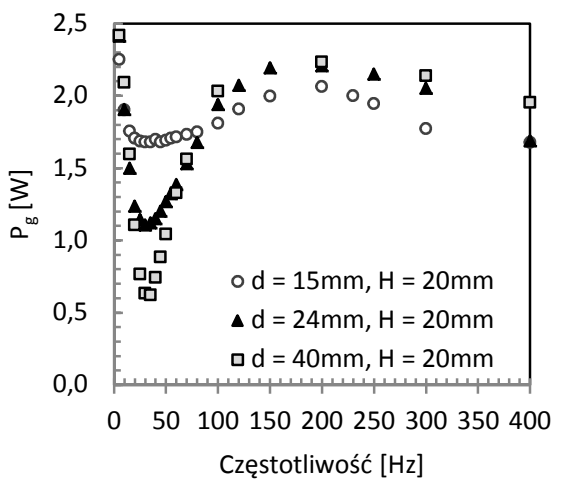

Rys. 3. Moc elektryczna głośnika dla zmiennej częstotliwości $f$ oraz średnicy $d$; głębokość komory $H=20 \mathrm{~mm}$, długość dyszy $t=5 \mathrm{~mm}$

Fig. 3. Speaker electric power variation for different frequencies $f$ and different diameter $d$; cavity depth $H=20 \mathrm{~mm}$, length of nizzle $t=5 \mathrm{~mm}$

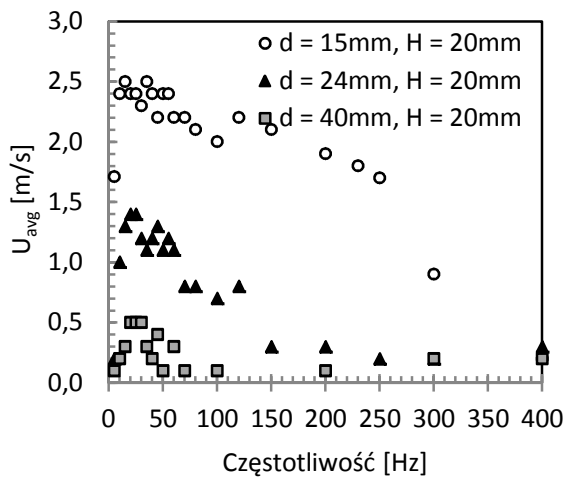

Rys. 5. Średnia prędkość powietrza $U_{\text {avg }}$ dla zmiennej częstotliwości $f$ oraz średnicy dyszy $d$; głębokość komory $H=20 \mathrm{~mm}$, długość dyszy $t=5 \mathrm{~mm}$

Fig. 5. Average air velocity $U_{a v g}$ for various frequency $f$ and nozzle diameter $d$; cavity depth $H=20 \mathrm{~mm}$, orifice length $t=5 \mathrm{~mm}$

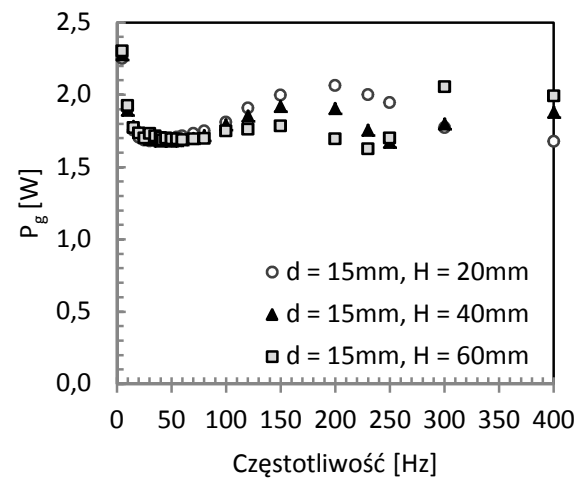

Rys. 4. Moc elektryczna głośnika dla zmiennej częstotliwości $f$ oraz głębokości komory $H$; średnica $d=15 \mathrm{~mm}$, długość dyszy $t=5 \mathrm{~mm}$

Fig. 4. Speaker electric power variation for different frequencies $f$ and different cavity depth $H$; orifice diameter $d=15 \mathrm{~mm}$, length of nozzle $t=5 \mathrm{~mm}$

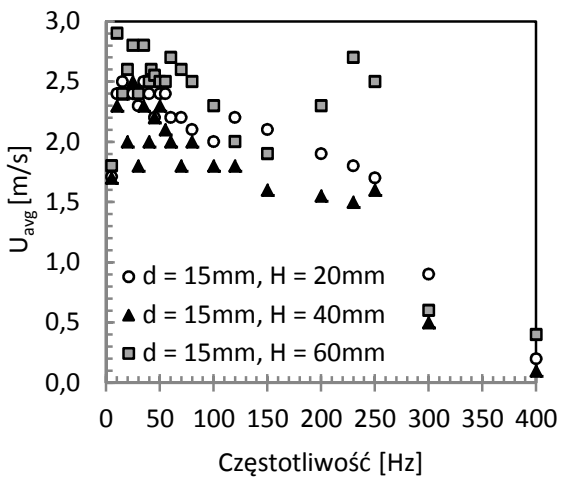

Rys. 6. Średnia prędkość powietrza $U_{\text {avg }}$ dla zmiennej częstotliwości $f$ oraz głębokości komory $H$; średnica $d=15 \mathrm{~mm}$, długość dyszy $t=5 \mathrm{~mm}$

Fig. 6. Average air velocity $U_{\text {avg }}$ for various frequency $f$ and cavity depth $H$; orifice diameter $d=15 \mathrm{~mm}$, orifice length $t=5 \mathrm{~mm}$

\section{Wnioski}

Struga syntetyczna nie powstaje przy wyższych częstotliwościach, ze względu na efekt równoważenia prędkości wytłaczania i zasysania powietrza 


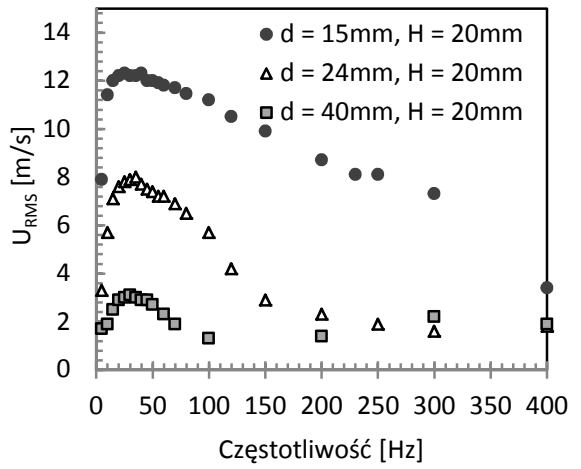

Rys. 7. Wartość skuteczna prędkości powietrza $U_{\text {RMS }}$ dla zmiennej częstotliwości $f$ oraz średnicy dyszy $d$; głębokość komory $H=20 \mathrm{~mm}$, długość dyszy $t=5 \mathrm{~mm}$

Fig. 7. Effective value of air velocity $U_{\text {RMS }}$ for various frequency $f$ and nozzle diameter $d$, cavity depth $H=20 \mathrm{~mm}$, nozzle length $t=$ $=5 \mathrm{~mm}$

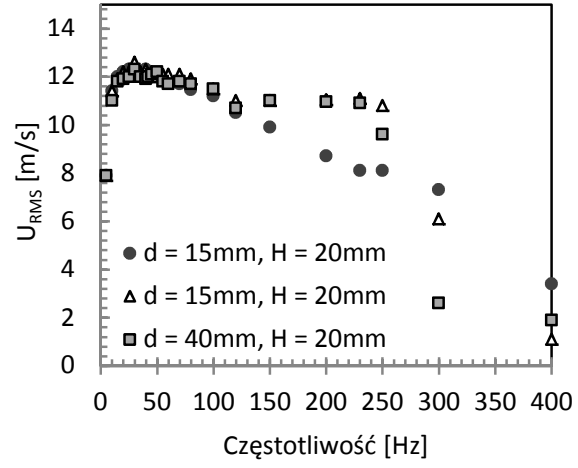

Rys. 8. Wartość skuteczna prędkości powietrza $U_{\text {RMS }}$ dla zmiennej częstotliwości $f$ oraz głębokości komory $H$; średnica dyszy $d=15 \mathrm{~mm}$, długość dyszy $t=5 \mathrm{~mm}$

Fig. 8. Effective value of air velocity $U_{\mathrm{RMS}}$ for various frequency $f$ and cavity depth $H$; nozzle diameter $d=15 \mathrm{~mm}$, nozzle length $t=5 \mathrm{~mm}$

do komory generatora strugi syntetycznej. Jednak równoważenie to nie występuje przy niskich częstotliwościach (rys. 5.) i struga syntetyczna powstaje. Zauważono dwa maksima prędkości średniej $U_{\text {avg }}$ dla objętości komory $H=40 \mathrm{~mm}$ oraz $H=60 \mathrm{~mm}$ (rys. 6.) oraz odpowiadające im minima lokalne mocy elektrycznej głośnika (rys. 4.). Gallas i in. [6] zasugerowali istnienie dwóch częstotliwości rezonansowych, co potwierdzono eksperymentalnie w pracy [4]. Pierwsza częstotliwość rezonansowa odpowiada częstotliwości własnej membrany, która dla głośnika użytego $\mathrm{w}$ tym opracowaniu wynosi $F_{s}=37 \mathrm{~Hz}$. Jest ona zależna od średnicy $d_{m}$, masy $m$ oraz właściwości materiałowych membrany [4]. Z kolei druga częstotliwość rezonansowa, określana częstotliwością Helmholtza, jest zależna wyłącznie od objętości komory $V$, średnicy dyszy $d$ oraz długości dyszy $t$. Uzyskane wartości częstotliwości rezonansowej są mniejsze niż podawane przez producenta, co jest spowodowane zwiększeniem masy membrany ze względu na przyklejenie płytki akcelerometru (zwiększenie masy drgającej) i(lub) błędem pomiaru.

Kryterium powstawania strugi syntetycznej było badane w pracach [7-9]. Dla dysz osiowosymetrycznych autorzy otrzymali zbieżny warunek powstawania strugi syntetycznej, tj:

$$
\frac{\mathrm{Re}}{\mathrm{Stk}^{2}} \geq 0,16
$$

Gdy prędkość średnia $U_{\text {avg }}$ jest wystarczająco duża oraz częstotliwość $f$ dostatecznie mała, wówczas występują korzystne warunki, przy których podczas 
cyklu zasysania płynu do komory nie jest niszczona struktura wiru wytworzonego podczas cyklu wytłaczania (rys. 9. i 10.).

Aby wytworzyć strugę syntetyczną, należy spełnić warunek Re/Stk ${ }^{2} \geq 0.16$. Jak widać na rys. 10., przy średnicy dyszy $d=15 \mathrm{~mm}$ struga syntetyczna występowała w zakresie częstotliwości $f=5-120 \mathrm{~Hz}$, gdy $d=24 \mathrm{~mm}-$ w zakresie częstotliwości $f=5-55 \mathrm{~Hz}$, natomiast gdy $d=40 \mathrm{~mm}$, struga syntetyczna nie występuje.

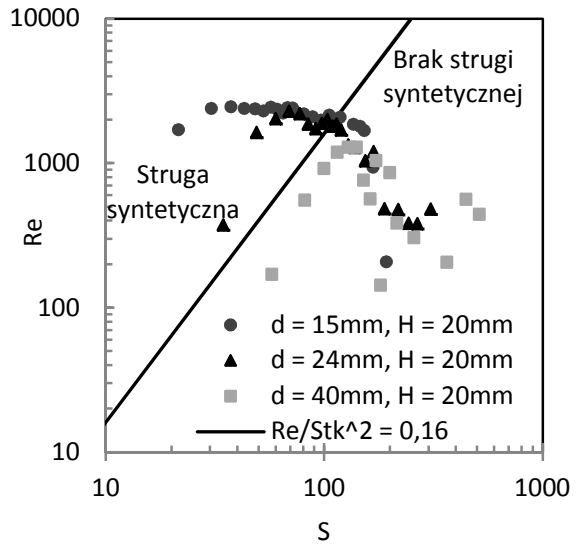

Rys. 9. Kryterium powstawania strugi syntetycznej; gdy Re/Stk ${ }^{2} \geq 0,16$, powstaje struga syntetyczna

Fig. 9. A criterion for synthetic jet formation; synthetic jet is formed for $\mathrm{Re} / \mathrm{Stk}^{2} \geq 0.16$

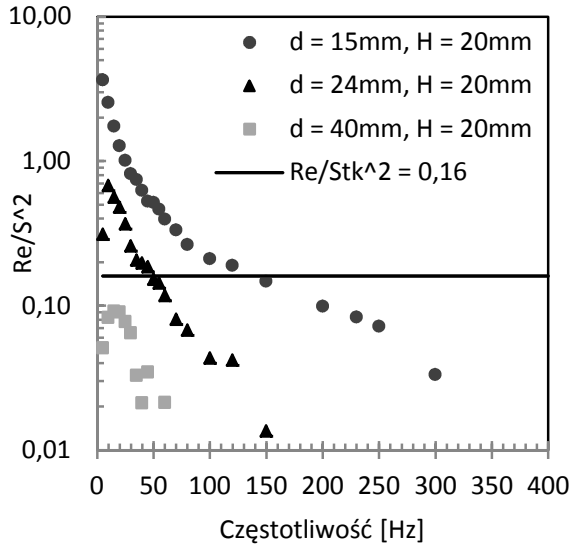

Rys. 10. Linia graniczna powstawania strugi syntetycznej

Fig. 10. Threshold of synthetic jet formation

\section{Podziękowania}

Prace były prowadzone na aparaturze naukowo-badawczej zakupionej w ramach projektu nr POPW.01.03.00-18-012 z funduszy strukturalnych Programu Operacyjnego Rozwój Polski Wschodniej, współfinansowanego przez Unię Europejską ze środków Europejskiego Funduszu Rozwoju Regionalnego.

\section{Literatura}

[1] Ingard U., Labate S.: Acoustic circulation effect and the nonlinear impedance of orifice. J. Acoustic Soc. Am., 22(2), 211-218.

[2] Smith B.L., Glezer A.: Vectoring and small-scale motions effected in free shear flows using synthetic jet actuators. AIAA 35th Aerospace Sciences Meeting, Reno 1997, 97-113.

[3] Smith B., Glezer A.: The formation and evolution of synthetic jet. Phys. Fluids, 10 (1998), 2281-2297. 
[4] Chaudhari M., Verma G., Puranik B., Agrawal A.: Frequency response of a synthetic jet cavity. Exp. Thermal Fluid Sci., 33 (2009), 439-448.

[5] Pavlova A., Amitay M.: Electronic cooling with synthetic jet impingement. J. Heat Transfer, 128 (2006), 897-907.

[6] Gallas Q., Holman R., Nishida T., et.al.: Lumped element modeling of piezoelectric-driven synthetic jet actuator. AAIA J., 41 (2003), 240-247.

[7] Holman R., Utturkar Y., Mittal R., et.al.: A formation criterion for synthetic jets. AIAA J., 43 (2005), 2110-2116.

[8] McGuinn A., Farrelly R., Persoons T. et.al.: Flow regime characterization of an impinging axisymmetric synthetic jet. Exp. Thermal Fluid Sci., 47 (2013), 241-251.

[9] Zhang P., Wang J., Feng L.: Review of zero-net-mass-flux jet and its application in separation flow control. Science in China Series E: Technol. Sci., 51 (2008), 1315$-1344$.

\section{A CRITERION FOR FORMATION OF SYNTHETIC JET}

\section{S u m m a r y}

The paper presents a criterion for the formation of a synthetic jet. The paper presents air velocity measurement in the axis of the nozzle of synthetic jet generator for various frequencies $f=5-400 \mathrm{~Hz}$, various nozzle diameters $d=15,24,40 \mathrm{~mm}$ and for various cavity depths $H=20$, $40,60 \mathrm{~mm}$. Electrical power of electroacoustic transducers was measured. Obtained values of Reynolds and Stokes numbers were compared with literature data, and the criterion for synthetic jet formation. Convergence of the obtained results was gained.

Keywords: synthetic jet, Reynolds number, criterion for jet formation, resonant frequency

DOI: $10.7862 / \mathrm{rm} .2014 .55$

Otrzymano/received: $2.06 .2014 \mathrm{r}$.

Zaakceptowano/accepted: 2.11.2014 $\mathrm{r}$. 
